\title{
EFFECT OF ALTHESIN ON RENAL PERFUSION IN ANAESTHETIZED DOGS
}

\author{
D. Patschke, J. Passian, J. Tarnow, and A. Weymar
}

\section{INTRODUCTION}

NUMEROUS CLINICAL AND EXPERIMENTAL ANIMAL STUDIES have shown that the new intravenous anaesthetic agent Althesin affects the total circulatory system. ${ }^{1-8}$ After the administration of Althesin, a dose-related rise in cardiac output due to an increase in heart rate and a decrease in mean aortic pressure induced by vasodilation $^{n}$ and/or decrease of the myocardial inotropic state was always observed. ${ }^{10,11,12}$ Moreover, some investigators have also focused their attention on the effect of Althesin upon circulation in certain organs, where flow is held constant or is adapted to varying energy demands by intrinsic autoregulatory mechanisms. Thus Pickerodt, ${ }^{13}$ Cohen ${ }^{14}$ and their associates have studied the behaviour of the cerebral blood flow during Althesin anaesthesia in animals. These authors reported conflicting data, probably the result of their different methods. Sonntag et al..$^{15}$ and Patschke et al. ${ }^{1: 2}$ have found an increase in coronary perfusion in man and dogs, respectively. But there are no reports concerning the autoregulated perfusion of the kidneys under the influence of Althesin. Since changes in renal perfusion pressure, internal blood distribution or total renal blood flow have been shown to produce marked changes in renal function, ${ }^{16,17}$ while on the other hand anaesthetic agents cause alterations of the renal circulation ${ }^{18}$ this experimental study was undertaken to explore the effect of Althesin upon the renal blood flow.

\section{METHOD}

The experiments were performed on 13 unpremedicated mongrel dogs ranging in weight from 22 to $39 \mathrm{~kg}$. In each animal anaesthesia was induced with $3 \mathrm{mg} / \mathrm{kg}$ piritramide (Dipidolor) and intubation was facilitated with $4 \mathrm{mg}$ diallyl-nortoxiferin (Alloferin, Roche). The animals were then artificially ventilated with $70 \%$ $\mathrm{N}_{2} \mathrm{O}$ and oxygen by means of an Engström respirator. Normoxic and normocapnic conditions were controlled by intermittent blood gas analyses (Astrup ${ }^{19}$ ) and by continuous measurements of end-tidal $\mathrm{CO}_{\Perp}$-concentration using an infrared gas analyser (Uras M, Hartmann \& Braun). Anaesthesia and muscle relaxation were maintained with small doses of piritramide and Alloferin as necessary.

Catheters were inscrted by the femoral artery and vein to measure the aortic and central venous pressures by pressure transducers (Statham P $23 \mathrm{Db}$ ). The left ventricular pressure and its first derivative $(\mathrm{dp} / \mathrm{dt})$ were measured using a high fidelity catheter-tip manometer (Millar PC 350) connected to an amplifier (Statham SP 1400). Cardiac output was determined by utilizing the thermo-dilution

Institute of Anaesthesiology, Free University of Berlin, Gemmany 1000 Berlin 19, Spandauer Damm 130 (Director: Prof. Dr. H.J. Eberlein). 
technique ${ }^{20}$ and heart rate was determined from the ECG lead II. An electromagnetic flow probe (inner diameter $4 \mathrm{~mm}$ ) was placed around the right renal artery through a right flank incision, employing the extraperitoneal approach, so that the probe was in direct contact with the arterial wall. The renal blood flow was measured using a flowmeter (Statham SP 2202) with non-occlusive Zero.

Previous blood flow instruments with non-occlusive zero features used sine wave, trapezoidal wave, and square wave forms for the probe magnet drive. However, the sine wave has serious phase-shift problems, the trapezoidal wave has turn-on and turn-off spikes, and the square wave poses problems in synchronizing two or more probes at the same time, i.e. when two probes are placed in proximity, the magnetic field of one probe will affect the other. The recent developed Statham electromagnetic blood flowmeters, model SP 2202, have resolved these problems by using a pulsed-field wave form. This pulsed wave form is particularly suitable for determination of non-occlusive zero, because it allows electronic sampling to be accomplished periodically between the reversals of positive and negative polarity at times when the flow signal is reading zero. This is done without any effect on the pulsatile response of the unit. It also leaves to the investigator the option of using an occlusive (mechanical) zero. We have checked the mechanical zero against the electronic zero of the Statham model SP 2202 in the animal experiments as well as in in vitro studies and could establish the scientific validity of the latter.

From the recorded variables the total peripheral resistance and the renal vascular resistance were calculated as the ratio of the mean aortic pressure minus central venous pressure to cardiac output per body weight in $\mathrm{kg}$ and to renal blood flow per $100 \mathrm{~g}$ kidney weight respectively. The renal fraction of cardiac output was calculated in terms of percentage values by dividing the measured renal blood flow by cardiac output $\times 100$.

When circulatory conditions were stable, a single dose of $2 \mathrm{mg} / \mathrm{kg}$ Althesin $(=0.17 \mathrm{ml} / \mathrm{kg}$ stock solution) was then intravenously injected within $20 \mathrm{sec}$. Haemodynamic responses were recorded over a period of 30 minutes. Approximately five hours prior to the administration of Althesin all animals received as prophylactic treatment $2 \mathrm{mg}$ of the powerful and long-acting antihistaminic agent meclastine (Tavegyl) intravenously in order to block reactions to histamine released by Cremophor EL, the solvent of the steroid anaesthetic agent. The antihistaminic has neither atropine-like nor quinidine-like nor adrenolytic properties and was found in a preliminary study not to affect the cardiovascular system.

Changes in the values of the determined variables during the first 10 minutes after administration of Althesin were evaluated for statistical significance by applying the Student's paired t-test.

\section{Results}

Table I shows the effect of Althesin upon haemodynamics and renal blood flow. Immediately after the injection of $2 \mathrm{mg} / \mathrm{kg}$ Althesin heart rate increased from 70 to 114 beats $/ \mathrm{min}(\mathrm{p}<0.005)$ reaching a peak after 10 minutes. Since stroke volume decreased only from 1.41 to $1.13 \mathrm{ml} / \mathrm{kg}(\mathrm{p}<0.005)$ during the same interval, 
TABLE I

Effect of $2 \mathrm{mg} / \mathrm{kg}$ Althesin Upon Heart Rate (HR), Stroke Volume (SV), Cardiac Output (CO), Mean Aortic Pressure (Parta), Total Vascular Resistance (TPR), Maximum Rate of Change of left Ventricular Pressure (dp/dt max), Renal Blood Flow (RBF), Renal Vascular Resistance (RVR) and Renal fraction of Cardiac Output $\left(\dot{V}_{\text {ren }} / C O\right)(\bar{x} \pm s \bar{x} ; n=13)$.

\begin{tabular}{llllll}
\hline & control & $1 \mathrm{~min}$ & $3 \mathrm{~min}$ & $5 \mathrm{~min}$ & $10 \mathrm{~min}$ \\
\hline $\mathrm{HR}$ & 70 & $96^{* *}$ & $95^{* *}$ & $102^{* *}$ & $114^{* *}$ \\
$(\mathrm{n} / \mathrm{min})$ & \pm 7 & \pm 9 & \pm 9 & \pm 9 & \pm 12 \\
$\mathrm{SV}$ & 1.41 & $1.19^{* *}$ & $1.15^{* *}$ & $1.11^{* * *}$ & $1.13^{* *}$ \\
$(\mathrm{ml} / \mathrm{kg})$ & \pm 0.16 & \pm 0.16 & \pm 0.12 & \pm 0.12 & \pm 0.16 \\
$\mathrm{CO}$ & 90.6 & $100.8^{*}$ & $99.0^{*}$ & $102.6^{*}$ & $110.0^{* *}$ \\
$(\mathrm{ml} / \mathrm{kg} \cdot \mathrm{min})$ & \pm 6.8 & \pm 7.4 & \pm 6.0 & \pm .65 & \pm 7.6 \\
$\overline{\mathrm{P}}_{\mathrm{Aorta}}$ & 115 & 111 & 112 & 108 & $105^{*}$ \\
$(\mathrm{mmHg})$ & \pm 3 & \pm 3 & \pm 3 & \pm 3 & \pm 3 \\
$\mathrm{TPR}$ & 1.29 & $1.12^{* *}$ & $1.13^{* *}$ & $1.05^{* *}$ & $0.97^{* * *}$ \\
$(\mathrm{mmHg} / \mathrm{ml} / \mathrm{kg} \cdot \mathrm{min})$ & \pm 0.11 & \pm 0.11 & \pm 0.09 & \pm 0.09 & \pm 0.09 \\
$\mathrm{dp} / \mathrm{dt} \max$ & 2829 & $2015^{* * *}$ & $1942^{* * *}$ & $2065^{* * *}$ & $2262^{* * *}$ \\
$(\mathrm{mmHg} / \mathrm{sec})$ & \pm 272 & \pm 230 & \pm 199 & \pm 206 & \pm 216 \\
$\mathrm{RBF}$ & 336 & 339 & 342 & 333 & 331 \\
$(\mathrm{ml} / \mathrm{min} \cdot 100 \mathrm{~g})$ & \pm 21 & \pm 22 & \pm 22 & \pm 23 & \pm 25 \\
$\mathrm{RVR}$ & 0.35 & 0.34 & 0.34 & 0.34 & 0.33 \\
$(\mathrm{mmHg} / \mathrm{ml} / \mathrm{min} \cdot 100 \mathrm{~g})$ & \pm 0.03 & \pm 0.03 & \pm 0.03 & \pm 0.03 & \pm 0.03 \\
$\dot{\mathrm{V}}_{\mathrm{ren}} / \mathrm{CO}$ & 8.7 & 7.9 & 8.0 & $7.6^{*}$ & $7.1^{* * *}$ \\
$(\%)$ & \pm 0.6 & \pm 0.5 & \pm 0.5 & \pm 0.5 & \pm 0.6 \\
\hline
\end{tabular}

Significance of the difference from control: ${ }^{*} \mathrm{p}<0.01 . \quad{ }^{* *} \mathrm{p}<0.005 . \quad{ }^{* * *} \mathrm{p}<0.001$.

cardiac output was raised by $19.4 \mathrm{ml} / \mathrm{kg} / \mathrm{min}$ above pre-injection level. Parallel with this, the mean aortic pressure fell from 115 to $105 \mathrm{mmHg}(\mathrm{p}<0.01)$ accompanied by a decrease in total peripheral resistance from 1.29 to $0.97 \mathrm{mmHg} / \mathrm{ml} /$ $\mathrm{kg} / \mathrm{min}(\mathrm{p}<0.001)$ and a decrease of the inotropic parameter $\mathrm{dp} / \mathrm{dt}$ max from 2829 to $1942 \mathrm{mmHg} / \mathrm{sec}(\mathrm{p}<0.001)$. In contrast to this, the renal blood flow and the renal vascular resistance did not change their control values of $336 \mathrm{ml} / \mathrm{min} /$ $100 \mathrm{~g}$ and $0.35 \mathrm{mmHg} / \mathrm{ml} / \mathrm{min} / 100 \mathrm{~g}$ respectively. Since the cardiac output increased significantly, the proportion of cardiac output perfusing the right kidney fell from 8.7 to 7.1 per cent $(\mathrm{p}<0.001)$.

All control values were reached within 20 to 30 minutes after drug administration.

\section{Discussion}

Althesin is a mixture of two steroid anaesthetic agents dissolved in Cremophor EL. Since Cremophor EL is believed to release histamine or histamine-like substances - especially in dogs ${ }^{21}$ - all animals were pretreated with a powerful antihistaminic prior to the experiment. Under these conditions Cremophor EL turned out to have no effect upon haemodynamics. Since furthermore the release of histamine requires a period of 3 to 6 minutes but the maximal haemodynamic changes had already occurred in the first minute after administration of Althesin, the observed circulatory response to the steroid anaesthetic agent seemed not to be mediated by histamine. ${ }^{11}$ 
The cardiovascular effects of a dose of $2 \mathrm{mg} / \mathrm{kg}$ Althesin suggested by Campbell in man were in agreement with the findings of other investigators. ${ }^{2-4,7.8}$ There was an average fall in mean aortic pressure of 9 per cent, a reduction in total peripheral resistance of 25 per cent and a rise in cardiac output of 21 per cent due to an increase in heart rate of 63 per cent. The inotropic parameter $\mathrm{dp} / \mathrm{dt} \max$ decreased by 31 per cent.

Although Althesin markedly affected the total circulatory system, in our experiments the renal blood flow remained unchanged. From this observation we can presume that kidney perfusion even under the influence of Althesin was held constant by an intrinsic autoregulatory mechanism within a range of perfusion pressure between 80 and $180 \mathrm{mmHg}$. In no animal did the mean blood pressure fall below $95 \mathrm{mmHg}$.

The renal fraction of cardiac output in normal resting man is about 21 per cent. ${ }^{22}$ In our experiments with animals anaesthetized with piritramide, the renal blood flow of the right kidney was 8.7 per cent of the cardiac output. Provided that the perfusion of the left kidney was of the same order, the total proportion of 17.4 per cent represented a physiological value. Since after the injection of Althesin the right renal blood flow remained unchanged but the proportion of the cardiac output decreased significantly from 8.7 per cent to 7.1 per cent, we can conclude, that there was a redistribution of cardiac output. This means that there was an increase in blood flow in some organic circulatory systems other than in renal circulation.

Haemodynamic studies have demonstrated that Althesin has no effect upon total renal blood flow as long as the perfusing pressure does not exceed the bounds of the autoregulatory mechanism. The results do not, however, give any information about the important internal distribution of blood flow to cortical and juxtamedullary nephrons as well as renal function and renal oxygen consumption. But these problems were beyond the scope of this study and should remain as a subject of further investigations with continuous Althesin infusion. Since the effect of an initial dose is of short duration, we believe that, based from the data of the above study under stable circulatory conditions Althesin can be used even in the presence of renal dysfunction.

\section{SUMMARY}

Since Althesin affects not only the systemic circulation but also certain regional blood fows autoregulated by intrinsic mechanisms, such as cerebral and coronary blood flow, the purpose of this study was to investigate the effect of Althesin upon renal blood flow.

After an injection of $2.0 \mathrm{mg} / \mathrm{kg}$ Althesin, heart rate (63 per cent) and cardiac output ( 21 per cent) increased, while total peripheral resistance ( 25 per cent), mean aortic pressure ( 9 per cent) and the maximum rate of change of left ventricular pressure ( 31 per cent) decreased. In spite of the large renal fraction of cardiac output ( 17.4 per cent) the renal blood flow remained unchanged.

Althesin is believed not to be contra-indicated in the presence of renal dysfunction. 


\section{RÉSUMÉ}

Des études expérimentales et cliniques ont montré que l'Althesin modifie non seulement la circulation systémique mais aussi des circulations régionales autorégularisées comme celles du cerveau et des coronaires; cette étude a voulu observer l'effet de l'Althesin sur la circulation rénale.

L'injection de $2 \mathrm{mg} / \mathrm{kg}$ d'Althesin a provoqué une augmentation de la fréquence (63 pour cent) et du débit cardiaques ( 21 pour cent) avec une diminution de la résistance périphérique globale ( 25 pour cent), de la pression aortique ( 9 pour cent) et de la vélocité maximale du changement de pression ventriculaire gauche ( 31 pour cent). Malgré la fraction importante du débit cardiaque destinée aux reins, la perfusion rénale est demeurée inchangée.

On croit donc qu'une dysfonction rénale ne contre-indique pas l'emploi de l'Athesin.

\section{REFERENCES}

1. Bradford, E.M.W., Miller, D.C., Campbell, D., \& Barro, W.L.W. CT 1341: Interaction with some anaesthetic agents. Brit. J. Anaesth. 43: 940 (1971).

2. Campeell, D., Forrester, A.C., Mrluer, D.C., Hutton, I., Kennedy, J.A., Lawrie, I.D.V., \& LOHIMER, A.R. A preliminary clinical study of CT 1341 - a steroid anaesthetic agent. Brit. J. Anaesth. 43: 14 (1971).

3. Child, K.J., Currie, J.P., Davis, B., Dodns, M.G., Pearce, D.R., \& Tisswell, D.J. The pharmacological properties in animals of CT 1341 - a new steroid anaesthetic agent. Brit. J. Anaesth. 43: 2 (1971).

4. Clatke, R.S.J., Montgomery, S.J., Dundee, J.W., \& Bovill, J.G. Clinical studies of induction agents XXXIX : CT 1.341, a new steroid anaesthetic. Brit. J. Anaesth, 43, 947 (1971).

5. Montgomeny, S.J., Clarke, R.S.J., Dundee, J.W., \& Bovml, J.G. Clinical studies with a new steroid anaesthetic, CT 1341. Brit. J. Anaesth. 43: 18 (1971).

6. Patschie, D., Bruckner, J.B., Reinecke, A., Schmicke, P., Tafnow, J., \& Eberlein, H.J. Experimentelle Untersuchungen der Kreislaufwirkungen von CT 1341, einem neuen Steroidanaesthetikum. Anaesthesist 21:338 (1972).

7. Sayege, T.M., Foley, Eleanor, I, Coultas, R.J., Walton, B., Strunin, L., Simpson, B.R., \& SCOTT, D.F. CT 1341: some effects in man. Anaesthesia 26: 402 (1971).

8. Swerdlow, M., Chakrabarty, S.K., \& Zahangir, M.A.M. A trial of CT 1341. Brit. J. Anaesth. 43: 1075 (1971).

9. GondH, T. Althesin on the heart in situ in the cat. Postgrad. med J. Suppl. 2, 48: 31 (1972).

10. Foex, P. \& Prys-Ronerts, C. Pulmonary haemodynamics and myocardial effects of Althe$\sin$ (CT 1341) in the goat. Postgrad. med. J. Suppl. 2, 48: 24 (1972).

11. HALL, L.W. Althesin in larger animals. Postgrad, med. J. Suppl. 2, 48: 55 (1972).

12. Patschke, D., Brǘckner, J.B., Gethmann, J.W., Tarnow, J., \& Weymar, A. Influence of Althesin on coronary blood flow and myocardial oxygen consumption in dogs. Acta. anaesth. scand. 18: 23 (1974).

13. Pickerodt, V.W.A., McDowall, D.G., Coroneos, N.J., \& Keaney, N.P. Effect of Althesin on cerebral perfusion, cerebral metabolism and intracranial pressure in the anaesthetized baboon. Brit. J. Anaesth. 44: 751 ( 1972 ).

14. Cohen, R.S., Creighton, R.E., Nisbet, H.I.A., McDonald, P., \& Steward, D.J. The effects of Althesin on cerebral blood flow and intracranial pressure. Canad. Anaes. Soc. J, 20, no 6: 754 (1973).

15. Sonntag, H., Schenk, H.D., Regensburger, D., Kettler, D., Knoll, D., Donath, U., \& BECKEF, H. Effects of Althesin (Glaxo CT 1341) on coronary blood flow and myocardial metabolism in man. Acta anaesth. scand. 17:218 (1973).

16. Hatch, R.D. \& Johnson, J.G. Intrarenal blood flow. Ann. Rev. Med. 20: 395 (1969). 
17. Leighton, K., Koth, B., \& Bruce, C. Pancuronium and renal perfusion: a comparison of neuromuscular blocking agents. Canad. Anaes. Soc. J. 21, 2: 131 (1974).

18. ReichmanN, W. Über die Regulation der Nierendurchblutung. Tierexperimentelle Untersuchungen mittels Nierenvenen-Katheterismus. Arch. Kreisl. Forschg. 49: 133 (1966).

19. Astrup, P. A simple electrometric technique for the determination of carbon dioxide tension in blood and plasma, total content in "separated" plasma at a fixed carbon dioxide tension ( $40 \mathrm{mmHg}$ ). Scand. J. clin. Invest. 8: 33 (1956).

20. Slama, H. \& Pinper, J. Direktanzeigendes Rechengerat zur Bestimmung des Herzzeitvolumens mit der Thermo-Injektionsmethode. Z. Kreisl.-Forsch. 53: 322 (1964).

21. Wirth, W. \& Hoffmeisteh, F. Pharmakologische Untersuchungen mit Propanidid. Die intravenose Kurznarkose mit dem neuen Phenoxyessigsaurederivat Propanidid (Epontol). eds. K. Horatz, R. Frey, \& M. Zindler, p. 17. Anaesthesiologie und Wiederbelebung, Bd. 4, Springer Verlag. Heidelberg, Berlin, New York ( 1965 ).

22. Gutyon, A.C. Textbook of Medical Physiology. 3rd ed., p. 471, W.B. Saunders Comp., Philadelphia and London (1968). 